\title{
Diffusion of energy-saving innovations in industry and the built environment: Dutch studies as inputs for a more integrated analytical framework
}

\author{
Carel Dieperink ${ }^{\mathrm{a}, *}$, Iemy Brand ${ }^{\mathrm{b}}$, Walter Vermeulen ${ }^{\mathrm{a}}$ \\ ${ }^{a}$ Copernicus Institute for Sustainable Development and Innovation, Utrecht University, Heildelberglaan 2, P.O. Box 80115, 3508 TC, \\ Utrecht, Netherlands \\ ${ }^{\mathrm{b}}$ Novem, The Netherlands Agency for Energy and the Environment, P.O. Box 8242, 3503 RE, Utrecht, Netherlands
}

\begin{abstract}
The need to improve eco-efficiency is indisputable, and the way forward is through widespread application of environmental innovations. Yet research into the dissemination of such innovations in the Netherlands has been limited in scope. Most studies tend to focus on the feasibility of a particular technology. Few try to explain how technology spreads throughout society. The explanatory factors discerned in these studies are often not related to each other. In this contribution the authors try to integrate different partial explanations for the diffusion of energy-saving technologies in industry and the built environment into one conceptual framework. This integration is based on a secondary analysis of relatively well-elaborated studies dealing with the diffusion of heat pumps, combined heat and power and condensing boilers in industry and the built environment. Core of the framework is the decision-making process of the potentially adapting actor. Characteristics of the actor and the networks in which the actor participates (government, market, society) could have impact on this decision-making process. Technological and economic characteristics of the innovation and more general context factors are also relevant as factors that influence the considerations made in the decision-making process. This conceptual framework can be used both in more elaborate research projects and in brainstorming projects to improve policymaking.
\end{abstract}

(C) 2003 Elsevier Ltd. All rights reserved.

Keywords: Diffusion; Innovation; Energy-saving technologies

\section{Introduction}

The goal of a sustainable society implies that in the future consumption of energy and raw materials must not go beyond the earth's capacity to recover its ecological balance. The speed at which fossil resources are being depleted must not be any greater than the pace at which alternatives to the use of those resources become available. Moreover, the resources must be fairly distributed at the global scale. One consequence of pursuing this goal is the unavoidable transition to a less energy- and resource-intensive mode of production and consumption. This calls for considerable improvement

*Corresponding author. Tel.: +31-0302532359; fax: +310302532746 .

E-mail addresses: c.dieperink@geog.uu.nl (C. Dieperink), i.brand $@$ novem.nl (I. Brand), w.vermeulen@geog.uu.nl (W. Vermeulen). in eco-efficiency. Weterings and Opschoor, among others, believe that eco-efficiency should be improved by a factor of 10-20 over the coming 50 years (Weterings and Opschoor, 1994; Jansen, 1997). Other voices have called for an improvement in efficiency by a factor of four, on average, over the coming 25 years (Von Weizsäcker et al., 1998; Raad voor het Milieubeheer, 1996; see also Reijnders, 1998). The Netherlands' environmental policy (specifically, the Policy Document on the Environment and the Economy and the Third and Fourth National Environmental Policy Plans) takes improvement of eco-efficiency as its starting point. For years, in fact, this has been part and parcel of the European Union's environmental policy (Commissie van de Europese Gemeenschappen, 1992, p. 27).

Changes along these lines cannot be made from one day to the next. The transition will depend not only on the presence of alternative technology but also on its 
diffusion, its dissemination and application in society at large. In other words, good technological options should not just lie on the shelf collecting dust. The diffusion of environmental and energy-saving innovations should be accelerated. One way to pave the way for policy aimed at stimulating and accelerating the diffusion of environmental innovations is by providing a coherent overview of the factors that influence the speed of diffusion. An approach, which starts with the demand side of innovations, can provide this insight. In this approach the central focus lies on the potential user or adopter of the innovation. As our review of the literature reveals, attention is paid to the demand side but the necessary insight is sparse and scattered. Moreover, little attention is devoted to efforts to integrate the body of knowledge on innovation and diffusion from the perspective of specific disciplines or specific fields of innovation. So the aim of this paper is the development of a coherent framework for the explanation of the (lack of) successes in the diffusion of energy-saving innovations. We have made an attempt to integrate diverse insights in the field of the diffusion of energy-saving technologies in industry and the built environment. The integration is based on a secondary analysis of existing Dutch studies. The analysis was guided by three central questions: which explanations for the diffusion of are found in the studies and which conclusions are drawn, how can the explanatory factors be clustered and how do these clusters relate to each other.

In this paper, we first review the pertinent literature on diffusion. As the diffusion of heat pumps, combined heat and power and condensing boilers is relatively well studied we concentrate our search for explanations on studies concerning these three innovations. An inventory is made of the explanations found in these studies. The explanations found are clustered into six categories of variables. These partial explanations will be examined first. Finally, we combine these factors to form an integrative framework.

\section{Diffusion studies}

Following Lambooij (1988, p. 13) innovations are defined as the introduction of something new. A technological innovation aims at a renewal of the production processes of a company. After a first adoption the innovation can also be adopted by other companies or by companies in other branches. Schumpeter (Lambooij, 1988, p. 16) conceptualises this dissemination process by using the term diffusion.

When graphed, the diffusion process usually takes the form of S-curves. These curves indicate how familiarity with and application of a technology develop over time. After a hesitant start comes a breakthrough stage, when knowledge and use of the technology spread rapidly. The pace of adoption levels off again over time. Explanations for the course of the diffusion - the form of the S-curve - are few and far between. As it turns out, individual researchers emphasise different aspects, leading to divergent viewpoints in the literature.

One of the key aspects that has been identified is the transfer of information among a heterogeneous population of potential adapters. Emphasis has also been placed on the role of learning processes and cooperation within innovation networks (Jacobs, 1990). Supply factors such as the economic characteristics of the innovation (trends in the costs of investment and operation, efficiency improvement, time span to recoup the development costs) and actions of suppliers did also get attention (Stoneman, 1983; Thirtle and Ruttan, 1987) as well as factors as the know-how present in the industry and its expectations regarding government policy. The significance of the government as a player is also generally acknowledged (see among others Kline and Rosenberg, 1986; Hemmelskamp, 1997). Various studies concentrate on the effectiveness of governmental policy on environmental technology or on specific incentives offered by that policy (see, e.g., Kemp, 1997; Arentsen and Hofman, 1996; Van der Doelen, 1989). Other authors have investigated how decisionmaking takes place on the application of innovations, with a special focus on the role of communication (Rogers, 1995).

Over the past few decades, quite a few, often policy supporting, studies were released on the diffusion of energy-saving innovations in industry and the built environment (Brand et al., 1999). Relatively many studies have traced how heat pumps (mechanical vapour compression), combined heat and power and highefficiency boilers have been adopted. The application of membrane technology, heat exchangers, and impulse drying has also been studied, and so have the introductions of photovoltaic cells and solar energy, as well as the use of insulation materials. Much of the literature consists of feasibility studies, dealing mainly with technical and financial bottlenecks. These studies demonstrate that many innovations do not even make it to the application stage, while many of the innovations that do get that far take a long time to really break through. Various studies show that considerable time (5-10 years) may pass from the point when an energysaving innovation becomes known until it is actually put to use. As it turns out, however, there are hardly any explicit and empirically grounded explanations of the extent to which energy-efficient innovations have been diffused. Moreover, the theoretical basis of the studies that are available tends to be thin. However, studies dealing with the diffusion of heat pumps, combined heat and power and high-efficiency boilers, do contain interesting starting points. 


\section{The diffusion of heat pumps, combined heat and power and high-efficiency boilers}

It is hard to make a statement about the degree of success of the innovation of heat pumps and combined heat and power, as the number of actors that potentially could adopt these technologies is not known. Besides, this group of potentially adopting actors is due to change, for adoption of the technology in one sector introduces opportunities for adoption in other sectors as well. Statistics available however show that some diffusion of mechanical vapour compression and combined heat and power has occurred. The picture concerning the diffusion of highly energy efficient boilers is more clear, for this diffusion can be related to the number of houses in the Netherlands.

Mechanical vapour compression is a heat pump technology, which is used in several industrial evaporation processes. The pump is based on the principle that the water vapour that escapes the evaporation processes is brought by the use of a mechanically driven compressor on a pressure and temperature level, which enables reuse. Mechanical vapour compression is applicable in industrial sectors like the food, drink and tobacco industries, the chemical industry and the manure processing industry. In the Netherlands the adoption stays behind other European countries. The number of installations showed a growth during the first half of the 1980s, but stopped since then. In 199858 installations were in use in the Netherlands (Luiten, 1999; Van Brummelen et al., 1998). These installations have reduced $\mathrm{CO}_{2}$-emissions with 84 ktonnes. The six studies that deal with the diffusion of mechanical vapour compression offer a reasonable insight in the diffusion processes. Olsthoorn (1993) studied the implementation of mechanical vapour compression in the Netherlands dairy industry. Fortuin and Dennebos (1993) and Delwel et al. (1994) were looking at the technological and economical potentials of the technology in, respectively, the food-, drink- and tobacco- and the chemical industry. Rooijers and Van Swigchem (1996) focussed on the conditions for the optimal implementation of the technology. The degree of diffusion of mechanical vapour compression in the Netherlands dairy, starch and chemical industry, was the research object of the study of Van Brummelen et al. Finally Eijgelaar (1998) tried to find barriers for the implementation of the technology in nine chemical companies.

Combined heat and power is a technology that produces both heat and power. The heat produced is used in the form of steam or hot water. This combined production enables the saving of quite a lot of energy, depending on the drive installation and the temperature level. The use of gas turbines for instance enables a saving in primary energy of about 30\% (Luiten, 1996).
Combined heat and power can be applied on a large or on a small scale. City heating is an example of an application on a large scale. Small-scale application can be found in common space heating, greenhouses, swimming pools, hospitals and houses. As it is easier to transport electricity than heat, companies with a combined heat and power installation should adjust the capacity to its own need for heat. Concerning the diffusion of combined heat and power the Netherlands are together with Denmark on the lead in Europe. Total capacity in the Netherlands grew between 1968 and 1993 from 840 to $2200 \mathrm{MW}$ (Blok and Farla, 1996). At the end of the 1960s especially big scale units were installed in the chemical industry. In the beginning of the 1980s also small-scale units were installed in other industrial sectors. Since then the emphasis was put on the smallscale non-industrial applications. Four studies focus on the diffusion of combined heat and power in the Netherlands. Blok (1993) and Blok and Farla (1996) try to explain the development of the technology in the Netherlands. Blok and Turkenburg (1994) made an inventory of the possibilities to enlarge the application of the technology in industry. Boonekamp and Van Hilten (1995) try to draw some lessons from the history of combined heat and power.

The high-efficiency boiler was put on the market in 1981. This boiler is $20 \%$ more efficient compared to a conventional boiler as energy losses in chimneys are less because of the use of extra or larger heat exchangers. In the Netherlands the market share of the high-efficiency boiler is the biggest of Europe (Haug et al., 1998, p. 40). This share showed a growth from $10 \%$ to $60 \%$ between 1988 and 1997. Explanations for this development can be found in studies of Brezet (1994) and Haug et al. (1998).

A comparison of the studies concerning the diffusion of the technologies mentioned above learns that the authors show up with several explanations for the degree of diffusion. These explanations overlap, however in none of the studies the analysis implies a systematic application of several clusters of variables. Most studies are limited in scope. Although this does not necessarily imply that the analyses are inadequate, the use of a broader list of potentially relevant variables could have resulted in a richer analysis. The explanations found in the studies can be clustered as follows:

- decision-making of the (potential) user;

- the characteristics of the (potential) user;

- the influences impinging upon the company (exerted by governments, the market, and society at large);

- the technical and economic characteristics of the technology;

- influences coming from the macro-context such as the price of energy. 
The question can be raised how these clusters interrelate. Following Vermeulen (1992) the central focus should be on the decision-making of the actor in its societal network. The characteristics of the actor can play a role as do the influences from the environment of the company (government, markets and society). Technical and economic characteristics of the technology and influences coming from the macro-context could also have their relevance. However they work indirectly as they influence the considerations of the potentially adopting actor. To our opinion it is useful to focus on the coherence of these clusters. Starting point for such a study is an analysis of the decision-making process at the corporate or the individual level.

\section{The decision-making process of (potentially) adopting actors at the corporate or individual level}

Whether or not a technological innovation is applied within a company or by an individual is the outcome of a more or less rational decision-making process. However, there has to be a serious occasion for embarking on a round of decision-making. Companies and consumers first have to feel compelled to adapt their current consumption and production processes. The impetus may come from the need to replace a depreciated installation. Capacity problems may arise. Maybe they want to ensure continued electrical service. Or the willingness to consider adopting an innovation may be prompted by a regulation prohibiting a company from releasing its cooling water. But in addition to a perceived need, the technological innovation must naturally be appropriate to the company's production apparatus. In order to fit in, the equipment has to meet certain company-specific technical conditions. Whether a company actually considers innovation options partly depends on the existence of a corporate energy and/or environmental policy and organisational provisions for their implementation.

A study of the diffusion of the technology for cogeneration (Blok and Farla, 1996) reveals that while this innovation was indeed implemented by power companies, elsewhere it was ignored. The reason was that improvements in the generation of electricity fell outside the mandate of the companies in question. Therefore, the innovation did not reach the decisionmaking stage. Meanwhile, the sharp rise in energy costs and the availability of subsidies discouraged companies from adopting the technology for combined heat and power.

Brezet (1994) studied how consumers decided whether or not to purchase a high-efficiency boiler. The study reveals differences between those who buy a boiler - that is, the adopters - and those who do not. Adopters prove to make an independent and well-informed decision, taking economic considerations into account. The nonadopters, on the other hand, base their decision largely on the advice of installation firms. Heeding the contractor's advice, non-adopters tend to purchase a conventional boiler. From the contractor's perspective, the high-efficiency boiler has clear drawbacks: its high price, difficulties that may arise when installing the equipment, and uncertainty about how it will operate. The customer's second-hand information on the product's features prove to play a role in the decisionmaking process.

To fully understand diffusion processes, some familiarity with the course of decision-making of the potentially adapting actor is thus essential. Two aspects are at issue here: the kind of arguments that are weighed; and the decision-making process itself (what prompts it, how information is used, the rationale for making assessments, role of third parties) (see for instance Vermeulen, 1992). With regard to the assessments made by users, diverse interests are weighed in varying combinations: besides economic, technical, and functional factors, the process also takes organisational issues into account as well as societal considerations, which include environmental and energy objectives. Factors such as an acceptable time frame for recouping expenditures and a good profit margin are of importance. However, a theoretical approach based exclusively on economic reasoning-provides insufficient grounds on which to adequately explain the behaviour of the (potentially) adopting actors.

\section{Corporate and individual characteristics}

The characteristics of a decision-maker could shed light on the adoption of an innovation. Consider, for instance, a company's financial and production characteristics. In addition, the firm's organisational and cultural characteristics should also be taken into account - such as the extent to which environmental management is integrated in the overall operation of the firm.

Some of the characteristics of a company prove to stimulate the diffusion of heat pumps, whereas others impede their spread. When a company's current installation is due for replacement or when capacity problems arise, the situation is ripe for diffusion (Rooijers and Van Swigchem, 1996). The opposite is true when there is no slack in the company's energy balance (the steam-power relation). The study that Olsthoorn conducted on the diffusion of multi-stage evaporators in the dairy industry (1993) adds the company's lack of know-how to the list of inhibiting factors. The disappointing diffusion of heat pumps in the dairy sector has also been ascribed to the conservative character of this branch of the agrarian 
economy (Rooijers and Van Swigchem, 1996). Fortuin and Dennebos (1993) note that investments in heat pumps are hampered by the fact that the operating hours of firms in the food, drink and tobacco industry are too short. The time it takes to earn back the investment proves to be too long.

The number of productive hours also determines the length of time it takes to recoup investments in combined heat and power generation (Blok and Farla, 1996). Having no tradition in generating electricity and lacking possibilities for direct use of the generated electricity within the plant are two other examples of corporate characteristics that inhibit the adoption of new technology (Blok, 1993).

Brezet (1994) also discusses the characteristics of individuals who do or do not purchase a high-efficiency boiler. Early adopters are individuals who take the initiative to gather information (mostly on the basis of their own professional experience) and perform their own cost-benefit analysis. At the other hand, it proved that social and demographic factors such as age and level of education have very little to do with their behaviour. The same is true for some situational factors: the type and size of the dwelling and its energy consumption played no role in the decision to install energy-saving equipment.

The corporate and individual characteristics explain diffusion indirectly. They may partly offer an explanation for the value that specific criteria are given in the considerations mentioned above, or to some extent they explain the relative weight attached to certain criteria. In addition, they can explain why some potential users see reasons to adopt an innovation, while others may ignore the innovation. Moreover, these characteristics can influence the potential users' degree of familiarity with the new technology.

\section{Society and the market}

Actors operating in the surroundings of the intended users of an innovation can play a key role in the innovation process. Such actors - suppliers, customers, installers, end users, firms within the same sector, and centres of expertise - can convince a firm or household to adopt an innovation or dissuade potential users from doing so. In this manner, they can play a role in disseminating knowledge about the innovation. They thereby exert their influence on the substance of the decisions and the relative importance that people attach to a range of considerations.

The literature takes little note of the role played by outside providers of information with respect to the diffusion of heat pumps. And even when those providers are mentioned, the authors hardly elaborate on their activities (Rooijers and Van Swigchem, 1996). Citing an obstacle to diffusion, a case study of the chemical industry describes how the heat pumps are made up of different components and that the agents and consultants hardly bother to push or promote them. It was thus not surprising to discover that companies barely showed any interest in them.

Studies conducted on combined heat and power generation point to the role that the electricity companies have played as an important reason for the growth of the technology (Blok, 1993; Boonekamp and Van Hilten, 1995). They discuss various factors at play in the background: the introduction of joint-venture constructions between the distribution company, the consumers of heating, and the financial institutions; and the smoothly running co-operation between the producers of energy and the companies that distribute it. Both the producers and distributors declared their willingness to bear the risks of introducing a district heating system. The influence of universities and other knowledge institutes proved to be minimal.

A smooth diffusion of high-efficiency boilers was obstructed for a long time by the uncooperative stance of the installation firms (Haug et al., 1998; Brezet, 1994). Another obstacle was the fact that the manufacturers and wholesalers did not collaborate enough on the development and marketing of the product. This stalled its introduction on the market.

Thus, multiple actors can play a role in the wider context of potential adopters. Mol (1995, p. 61) offers an example of a systematic research on the role of actors operating in the surroundings of companies. In this regard, government policy deserves special mention, as the government promotes energy-saving technology.

\section{Government policy}

The government is an actor that has to play a remarkable role. In promoting diffusion government can use several types of policy instruments. However, various kinds of policy instruments have different effects. The more classic instruments (such as the requirements stipulated in permits) mainly have a direct effect through the assessments that the adopters make. In other cases, an instrument will mainly influence the characteristics of companies (for instance, by stimulating them to set up environmental management systems). Yet other instruments work mainly by activating the players in the corporate setting. For example, many modern R\&D instruments require co-operation between the business community and the knowledge infrastructure. These issues have not been given due consideration in the innovation studies discussed here.

Studies on the diffusion of mechanical vapour compression heat tend to gloss over the role of government. Rooijers and Van Swigchem (1996) 
perceive the government prohibition on discharge of cooling water as a major impulse for the introduction of mechanical vapour compression in the chemical industry. There is no reason to suppose that subsidies have had any stimulating effect. The introduction of a subsidy system did not lead to a higher rate of diffusion.

Yet for cogeneration of heat and power, policy did have a stimulating effect (Boonekamp and Van Hilten, 1995; Blok, 1993). Diverse investment subsidies have lowered the investment costs, thereby reducing the length of time it takes to recoup the expenditures to an acceptable level. Besides, as a result of the multi-year agreements that were made with the energy sector, the power companies have started up joint ventures with the firms that apply the technology. And those joint ventures, in turn, stimulated diffusion (Blok and Farla, 1996). A stimulating effect also came from the introduction of a restrictive policy on the amount of natural gas used and from raising the amount of compensation that the distribution companies receive when they deliver energy back to the grid. The same applies to setting up a special project office for the purpose of promoting the use of combined heat and power. Other instruments, such as subsidies to conduct feasibility studies and loans to make investments, have had no impact, according to the literature.

Various government programs designed to stimulate the use of high-efficiency boilers seem to have been successful too (Haug et al., 1998). It remains unclear how much importance we should attach to these government interventions, since there were also other governmental activities that inhibited adoption of the technology. From the point of view of manufacturers and wholesalers, the development of the boilers has been inhibited by an array of regulations for natural gas appliances (Brezet, 1994).

The literature generally mentions the influence government policies only in passing. Even when the studies do give attention to the role of government, they usually treat one or a few of the instruments in force at the time of study. Diffusion processes are of long duration, however. To do justice to the influence of policy, an analysis will have to give deep coverage to the dynamics of government intervention over a specified period. It is also necessary to take the whole mix of instruments into consideration-for both energy and environmental policy - as well as any other regulations pertaining to the target group or related to the technology. The studies would have to investigate the means and the extent of influence on the diffusion process. This would include direct regulation (by way of setting standards, issuing permits, and so forth), economic instruments (fees and the rapid succession of stimulating regulations at that time), communicative instruments, and forms of self-regulation such as target-group policy, agreements with the private sector, environmental management (organisational changes aimed at 'continual improvement' of environmental performance), and certification (EMAS, ISO 14,000 series) in the course of time.

Efforts to chart the influence of government policy on diffusion processes are crucial. They require a more comprehensive approach than is commonly used in research on the topic.

\section{Technical and economic characteristics of the innovation}

The extent of diffusion may also be explained in terms of the technical and economic characteristics of the innovation.

The study by Rooijers and Van Swigchem (1996) illustrates just how difficult it can be to adopt an innovation. In one case, the problem was that the heat pumps were closely integrated in the production process. And in order to implement multi-stage vapour compression, the entire production process would have to be adapted. Understandably, companies were usually reluctant to go that far. In fact, competing optionssuch as combined heat and power or thermal vapour compression-were also available. Even though the latter option has a much lower energy-saving effect, this technique requires less maintenance and is easier to operate (Olsthoorn, 1993). Initially, companies in that particular branch of industry preferred the latter option. However, Fortuin and Dennebos (1993) point out some characteristics of the heat pump that promote its diffusion. For one thing, companies appreciate the simpler construction and compact design of the multistage vapour compression technology. The authors noted its 'pleasant added benefit'-that the odour emitted from a brewery could be reduced thanks to the heat pump. Of course, the costs of acquisition and the efficiency of the equipment are critical to an explanation of its diffusion (Rooijers and Van Swigchem, 1996). The same authors also note that the amount of energy generated would hardly be sufficient to convince a company to install multi-stage vapour compression heat pumps.

Combined heat and power is based on a completely different technology than the heat pump. There is no need for process integration in cogeneration, since this technology operates on the periphery. In other words, cogeneration does not impinge upon the core of the production process; it merely changes the way energy is supplied. Thus, fitting the technology into the production process was not the problem. The diffusion of combined heat and power was delayed by the numerous start-up problems that arose after it was put on the market. Moreover, the higher levels of $\mathrm{NO}_{x}$ that are normally associated with combined heat and power undermined the environmentally friendly image of this 
innovation (Boonekamp and Van Hilten, 1995). Efficiency and the length of time it takes to recoup the investments were also important considerations in the decision on whether or not to implement the combined heat and power technology (Blok, 1993).

When high-efficiency boilers were introduced, factors such as technical fit, efficiency, and susceptibility to breakdowns were also important (Brezet, 1994; Haug et al., 1998). In light of the high price of the equipment and the unfavourable cost-benefit relation, the nonadopters perceived major obstacles to acquisition. In contrast, it was precisely the adopters' own cost-benefit analysis that convinced them to take the new technology on board.

Technical and economic characteristics and the associated image of an innovation definitely deserve a place in studies of diffusion. In fact, any difference between the way the supplier judges these characteristics and the way they were perceived by the intended users may largely explain why diffusion has been an uphill battle. Technical characteristics can thus influence the diffusion processes indirectly through potential user's perceptions. The technology's economic performance will play a key role in the assessments of companies as well as consumers. But at the same time negative images of an innovation may very well prevent potential users from even considering their application. Whether they are good informed or not is not relevant here. Therefore, objective assessments provided by suppliers or other experts should analytically be distinguished from assessments made by potential users. Furthermore, their final assessments will in many cases not exclusively be based on economic criteria.

\section{Influences from the macro-context}

Ultimately, some of the factors that play a role in diffusion derives from society at large, the macrocontext.

Rooijers and Van Swigchem (1996) note the importance of the market outlook within a certain sector. Poor prospects reduce the willingness to invest in heat pumps. This is what happened in the dairy industry, for example. In addition, a second context factor, the relatively low price of energy proved to have a negative impact on the willingness to invest in energy-saving technology for the food, drink, and tobacco industry (Fortuin and Dennebos, 1993).

Boonekamp and Van Hilten (1995) emphasise how the growing awareness of the greenhouse effect has influenced the diffusion of new technologies. At the end of the 1980s, global warming became a hot issue among all ranks of society. This public attention gave impetus to the introduction of energy-saving options. Driven in part by the more stringent environmental and energy policy - the government's response to the evidence of the greenhouse effect - the SEP (the former Organisation of energy producers in the Netherlands) and the energy distribution companies agreed to dismantle the most critical barriers to the diffusion of combined heat and power generation. However, the subsequent removal of these obstacles created overcapacity, which in turn blocked further diffusion (Blok and Farla, 1996).

Macro-developments also play a role in the diffusion of high-efficiency boilers. For a long time, the price of energy was so low that companies could hardly reap any return on the investments (Brezet, 1994). Meanwhile, the extensive network of gas pipelines in the Netherlands had a positive effect. In contrast, the diffusion of highefficiency boilers was considerably less brisk in France in the absence of an extensive infrastructure of gas pipelines (Haug et al., 1998).

Macro-developments must not be ignored in diffusion research, even though the effect of these factors is only indirect. They have an impact through assessments and the characteristics of the company. Nonetheless, the only way to do justice to the influence of macrofactors-just like that of government policy - is by carrying out a long-term analysis.

\section{Synthesis}

In the paragraphs 4-9, based on the secondary analysis of empirical studies, six clusters of explanations have been discussed. At this stage we need to enlarge our understanding of diffusion processes by clarifying the relative importance of these clusters of explanations. We propose to combine these explanations as inputs in the decision-making process, thus forming a research framework as shown in Fig. 1.

Using the framework, researchers could explain why some innovations diffuse and other do not. Essentially, the framework places the decision-making process (the occasion, the assessment, and the weighing of various criteria) of the potential users of innovations at the core and embeds it in corporate characteristics (in the case of a company). The variables referring to the context of the user (both the socio-economic and the policy setting), the technical and economic characteristics of the innovation, and the characteristics of the macro-context have an indirect effect. They operate in various ways through the decision-making of potential users.

It is important to stress here that decision-making about possible innovations on the level of individual firms is not an automatic consequence of favourable techno-economic features of an innovation; as it is neither an automatic consequence of coercive or strong stimulating policy activities. Deliberately we present a firm's decision-making as a four steps process. Assessments of new available technologies are just the final 


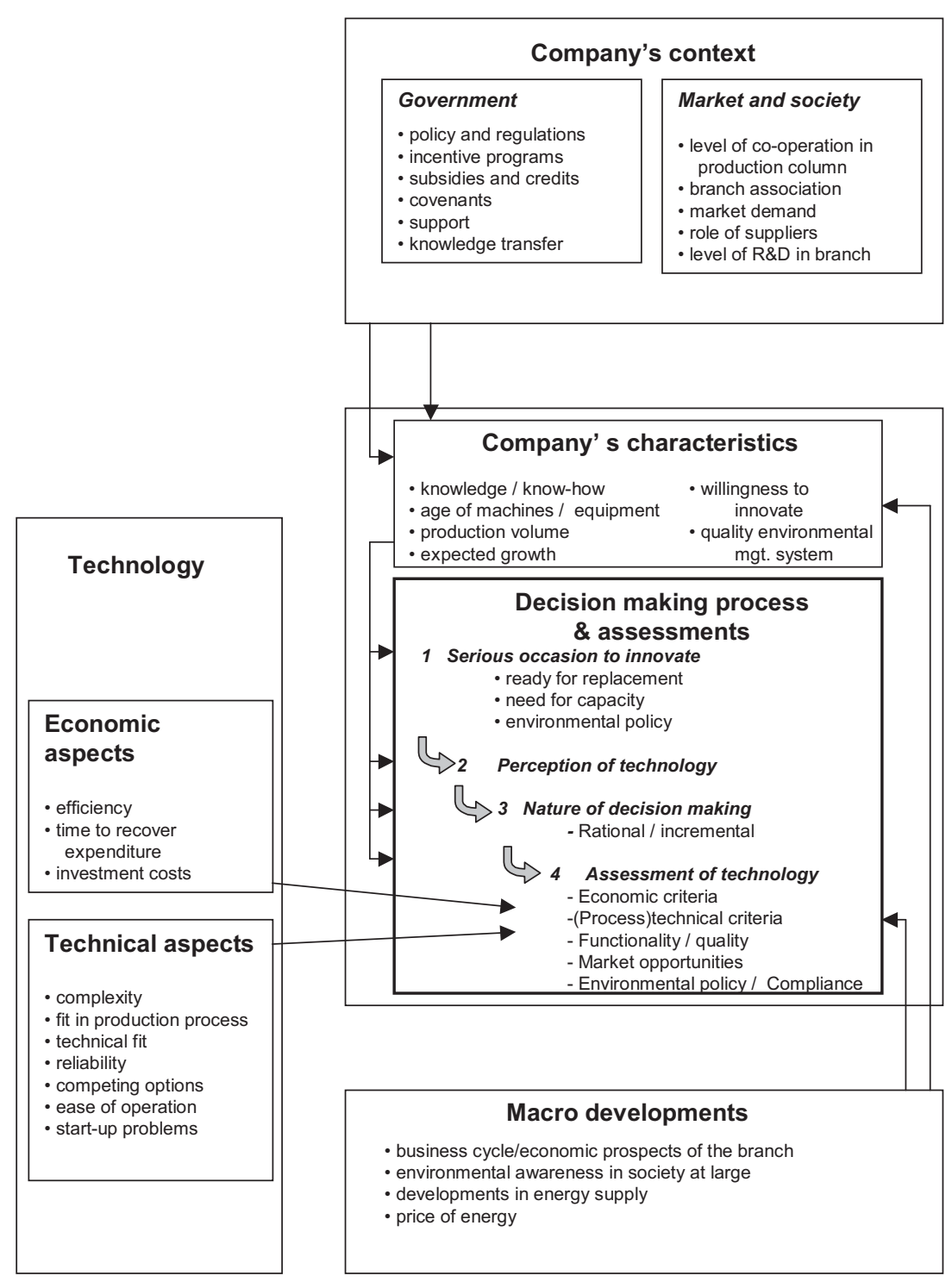

Fig. 1. Integrative framework explaining diffusion of innovations.

step in this sequence. In order to consider a new technology at all a company will need a serious occasion to allow one self to distract attention from its core business (step 1). In addition, a non-constraining initial perception of the quality of the innovation will be needed (step 2). Then the nature of decision-making procedures, mainly influenced by the firms characteristics (procedural culture and organisation, etc.), will determine the thoroughness of the assessment (step 3). In economic analyses these are often implicitly preproposed to be of synoptic-rational nature. However, empirical question always is, how much effort is given to such examinations, which of the perceivable assessment criteria are actually applied in practice and what values they are given (step 4).

Taking this combination of "companies characteristics" and "decision-making features" as the core of the model enables us to illustrate the mechanisms of influence of other explanatory variables on the factual adoption. For instance, time needed to recover investments can be analysed objectively as a feature of a specific innovation. But to be an explanation for adoption one should analyse how companies deal with this criterion, whether they come to the stage of assessing criteria at all. If so, the company can abstain from an investment, as it takes too long to recover the costs.

Another example may be the technical fit of a technology. In general, a technology may be judged to be widely applicable. Here again, to be an explanation for (non-) adoption it should be clear that companies in question decided the innovation to be applicable in their situation. Here company characteristics, like the age of their existing machines and equipment or their willingness to innovate, may be important intervening variables. 
In general, variables stated under the headings of "technology" or "macro-developments" can be said to be indirect explanations, as their influence depends on conscious consideration in step 4 of the decision-making process and are subjectively given a relative weight.

The "company's characteristics" as cluster of variables may offer explanations for the question whether steps 1,2 or 3 of the decision-making process are 'passed' and may add to the explanation of assessments made in practice.

The role of influencing activities of actors from the company's context may also be described as indirect. Policy intervention may affect either the company's characteristics (e.g. promotion of environmental management systems), or the various steps of decisionmaking. Regulations and voluntary agreements tend to contribute to the occurrence of a serious occasion and to offer motives for the application of innovations despite poor economic performance. Perceived market demand and activities of competitors may contribute to the relative value of other motives (market opportunities/ keeping up with the market). By modelling the process in this manner, we can combine divergent insights from the fields of technology dynamics, the sociology of innovation, policy sciences, and business administration.

The framework we propose is not unique as several factors are also discerned by leading authors in the field like Rogers, Daft and Kemp. Although most of our variables overlap with those used by others, some differences exist. According to Rogers (1983, p. 233) the rate of adoption of an innovation depends on five clusters of variables: the perceived attributes of innovations (their relative advantage, compatibility, complexity, observability and trialability being the degree to which an innovation may be experimented with on a limited basis); the type of innovation-decision (the number and authority of persons involved in making the innovation decision); the presence of communication channels (e.g. mass media or interpersonal); the nature of the social system (e.g. its norms and degree of interconnectedness, etc.) and finally the extent of change agents promotion efforts. Rogers models the innovation decision-process in five stages: the knowledge stage, persuasion stage, decision stage, implementation stage and confirmation stage. However both models are not explicitly related. In Rogers' explanatory model decision-making is only one of the five clusters of potentially explanatory factors. In our model the decision-making process and assessments is the focal point for the research. Also other recent studies show the importance of expanding Roger's model with policy process related variables (e.g. Van der Waals, 2001, pp. 131-141).

Daft (2001, p. 358) states that innovations, the adoption of an idea or behaviour that is new to the organisation's industry, market or general environment, are typically assimilated into an organisation through a series of steps or elements. Organisation members first become aware of a possible innovation, evaluate its appropriateness, and then evaluate and choose the idea. Successful changes will occur if internal creativity and inventions will result in ideas, a need, a perceived gap between actual and desired performance is present, if the decision makers choose to go ahead with a proposed idea and finally if organisation members actually use a new idea, technique or behaviour. To bring about change resources, human energy and activity are required. Suppliers, professional associations, consultants, research literature may influence the ideas within an organisation. Impacts on needs of an organisation come from customers, competition, legislation and regulation and labour force. All these elements should be present otherwise the change process will fail (see also Verheul, 1999; Mac, 2002). Although Daft's and our variables overlap, some differences are perceived. Our model differs from Daft's approach for it is explicitly meant to do research on the diffusion of technological innovations. Daft does not mention economic and technical aspects, for his model is more abstract and focuses on successful changes within organisations.

Diffusion of innovation in the view of Kemp et al. (1998) depend on what they call the existing technological regime. The whole complex of scientific knowledge, engineering practices, production process technologies, product characteristics, skills and procedures and institutions and infrastructures that make up the totality of a technology is called a technological regime. This phenomenon is further specified into barriers to explain a slow diffusion of preferable technologies. Explanations for a slow diffusion can be found by focusing on technological factors, government policy and regulatory framework, cultural and psychological factors, demand and production factors, required infrastructure and maintenance and the undesirable societal and environmental effects of technologies. Technological regime shifts may result from strategic niche management being the creation, development and controlled phase-out of protected spaces for the development and use of promising technologies by means of experimentation with the aim of learning about the desirability of the new technology and enhancing the further development and the rate of application of the new technology (see also Rip and Kemp, 1998; Arentsen et al., 2002). Apart from the vocabulary used this model hardly differs from our approach. Cultural and psychological factors are for instance specified in our framework in company's characteristics like willingness to innovate and in macro-developments like environmental awareness in society at large.

Summarizing, we may state that our explanatory framework is rich enough to be used in in-depth studies. It might be improved a little by adding some elements discerned by Rogers and Daft. Following Rogers's 
trialability has to be added to the technical aspects of an innovation and the type of innovation-decision (optional, collective, authority) to the company's characteristics. In our model the dependent variable is implicitly modelled being the result of the decision-making processes whereas Daft explicitly mentions adoption and implementation. This could be a valuable extension of our model. Another element to be added from Daft's model to our model is the possible impact consultants may have on diffusion, although this factor is not mentioned in the empirical studies on which our model is based.

\section{Application}

In the vein of the preceding, Brand and Van Westerop (1998) have attempted to make a comprehensive analysis. Besides dealing with technological and economic aspects, they include characteristics of the company while also devoting ample attention to policy. They have investigated the process of diffusion of environmentally friendly options in the printing business: computer to plate and film technology; ceramic moisture rollers, a new type of detergent (K3/VCA/ HBS), and inkjet technology. Their study suggests that companies will only decide to adopt an innovation if it will yield a profit. Printers are shown to be environmentally conscious, and environmental arguments do play a role in their decision-making on whether or not to adopt an innovation. But whether or not they take the step to actually follow an environmentally friendly course will depend on the price. In many cases, they choose the relatively inexpensive option of introducing new detergents instead of the expensive option of investing in computer technology.

With respect to the corporate characteristics, the same authors show that larger companies implement more innovations, on average, than smaller firms. Actually, that is not surprising, since it is usually easier for a large company to bear financial risks. Moreover, larger companies have more highly educated employees and tend to have an environmental care system or an environmental co-ordinator. Incidentally, we are not looking at a black and white distinction between large companies and small ones; small firms also demonstrate a willingness to innovate. A company's market position also forms an incentive to adopt an innovation. Companies with a growing production volume tend to be more innovative. The innovative firms also tend to make a greater effort to keep up with the ideas published in specialised trade journals. Besides, they seek out information on particular new developments by asking their suppliers specific questions, and they often consult their colleagues (Brand and Van Westerop, 1998).
It is striking that the researchers ascribe such a modest role to government policy. A covenant that had been arranged by the sector with the government has had little impact, apparently because the fact sheet that was required to back it up was considered to be too complicated to prepare. And a visit from the environmental inspector did not help the cause of innovation either, particularly in the smaller municipalities. In larger towns, the inspectors generally organise their work by project and are more specialised. With their expertise, they can respond better to the situation in individual companies; there, they do have some of influence on the decision to innovate.

In light of these findings, the authors recommend a management strategy that is specific to the target group. That strategy may be summed up as follows: to demonstrate the economic advantage of the environmental innovation; to make focused use of information channels (that is, information from suppliers and trade publications); to introduce simple incentives to reward innovative behaviour; and to increase the expertise of the environmental inspectorates.

\section{Conclusions}

In order to chart the factors that influence the diffusion of environmental innovations, we have performed a secondary analysis of studies on the introduction of a few energy-saving innovations in industry and the built environment. As it turns out, the literature uses only a limited number of variables to explain the extent and speed of diffusion of innovations to conserve the environment and to save energy. The framework we synthesise at the end of this paper is presented as a means to expand the scope of future research.

Although the framework is based on a secondary analysis on studies dealing with the diffusion of energysaving innovations, the framework could also be used to understand the diffusion of other environmental innovations. An interesting option would be to start a more quantitative analysis of diffusion processes with a special focus on the relative weight of the explanatory variables discerned. Such research should on the one hand include the analysis of the indirect influences of clusters of explanations in the three boxes surrounding the central box in the model addressing the company's context, the characteristics of the technology and macrodevelopments. On the other hand, such research should concentrate on company's characteristics and the various steps in decision-making processes. In a questionnaire actors could be asked to give the relative weights of the various criteria in their decision-making.

In the development of both environmental and energy policy, the framework can serve a heuristic function. It may prove useful for setting clear starting points for 
policy formulation with more attention on the demand side of diffusion processes. Through interactive brainstorming sessions with target groups policy makers can get an impression of their willingness to innovate and relevant strategies to remove barriers. Such brainstorming sessions might result in only a limited number of strategically relevant variables, like price developments in combined synergistic effects with energy conservation policies (regulation, standards, incentives, energy taxation) (see for instance Schipper and Meyers, 1995). Besides it can become clear what role the various actors have to play to realise the envisioned transition.

\section{References}

Arentsen, M.J., Hofman, P.S., 1996. Technologie: Schone motor van de economie? Een onderzoek naar de werking van het Programma Milieutechnologie in de periode 1993-1995 Enschede, Universiteit Twente, Center for Technology and Environmental Policy (CSTM), CSTM-SR, nr. 33.

Arentsen, M., Kemp, R., Luijten, E., 2002. Technological change and innovation for climate protection: the governance challenge. In: Kok, M.T.J., Vermeulen, W.J.V., Faaij, A.P.C., de Jager, D. (Eds.), Global Warming and Social Innovation: the Challenge of a Climate Neutral Society. Earthscan Publications Ltd., London/ Sterling, VA, pp. 59-81.

Blok, K., 1993. The development of industrial CHP in the Netherlands. Energy Policy 21 (2), 158-175.

Blok, K., Farla, J., 1996. The continuing story of CHP in the Netherlands. International Journal of Global Energy Issues 8 (4), 349-360.

Blok, K., Turkenburg, W., 1994. $\mathrm{CO}_{2}$ emission reduction by means of industrial CHP in the Netherlands. Energy Conversion and Management 35, 317-340.

Boonekamp, P.G.M., Van Hilten, O., 1995. Lessen uit de ontwikkeling van warmte/kracht. Energie-en Milieuspectrum, 4(12), Novem/ ECN.

Brand, I., Van Westerop, R., 1998. Variaties in milieu-innovaties; een onderzoek naar het invoeren van milieu-innovaties bij offsetdrukkerijen in Nederland. Universiteit Utrecht, Vakgroep Milieukunde, Utrecht.

Brand, I., Dieperink, C., Vermeulen, W.J.V., Booij, H., Engelen, J., Ros, J., 1999. Diffusie van milieu-innovaties, Een secundaire analyse van studies naar de diffusie van energiebesparende technologieën ten behoeve van modelontwikkeling. Novem, Utrecht.

Brezet, J.C., 1994. Van prototype tot standaard; De diffusie van energiebesparende technologie Een onderzoek naar het diffusieproces van Hoog-Rendement CV-ketels in de particuliere huishoudelijke sector in Nederland over de periode 1981-1992. Denhatex, Rotterdam.

Commissie van de Europese Gemeenschappen, 1992. Op weg naar duurzame ontwikkeling, Een beleidsplan en actieprogramma van de Europese Gemeenschap op het gebied van milieu en duurzame ontwikkeling. Brussel COM (92), 23 def.

Daft, R.L., 2001. Organization Theory and Design. Thomson Learning South-Western, Cincinnati.

Delwel, A., Doldersum, A., Kerkhof, F., 1994. Warmtepompen in de Nederlandse chemische industrie, Mogelijkheden en beperkingen. Comprimo B.V, Amsterdam.

Eijgelaar, M., 1998. Market study of heat pumps in the Dutch chemical industry Groningen/Enschede. TSM Business School HiTech Marketing Project.
Fortuin, J., Dennebos, M., 1993. Mechanische dampcompressie in de voedings-en genotmiddelenindustrie in Nederland; een onderzoek naar het technische en economisch potentieel van MDC. Tebodin, Den Haag.

Haug, J., Bode, J., Vis, J., Van Wijk, A., 1998. Evaluation and comparison of utility's and governmental DSM-Programmes for the promotion of Condensing boilers, Stuttgart, Universität Stuttgart, Institut für Energiewirtschaft und Rationelle Energieanwendung (IER).

Hemmelskamp, J., 1997. Environmental policy instruments and their effect on innovation. European Planning Studies 5 (2), 177-194.

Jacobs, D., 1990. The Policy relevance of Diffusion, report for Policy Studies on Technology and the Economy. Ministry of Economic Affairs of the Netherlands, The Hague.

Jansen, J.L.A., 1997. DTO-visie 2040-1998 Technologie, sleutel tot een duurzame samenleving. Ten Hagen \& Stam, Den Haag.

Kemp, R., 1997. Environmental Policy and Technical Change. A Comparison of the Technological Impact of Policy Instruments. Edward Elgar, Cheltenham.

Kemp, R., Schot, J., Hoogma, R., 1998. Regime shifts to sustainability through processes of niche formation: the approach of strategic niche management. Technology Analysis and Strategic Management 10 (2), 175-195.

Kline, S.J., Rosenberg, N., 1986. An overview of Innovation. In: Landau, R., Rosenberg, N. (Eds.), The Positive Sum Strategy: Harnessing Technology for Economic Growth. National Academy of Engineering, Washington, DC.

Lambooij, J.G., 1988. Regionale economische dynamiek; een inleiding in de economische geografie. Dick Coutinho, Muiderberg.

Luiten, E., 1996. Clusters rond duurzame energietechnologieën. Utrecht, Universiteit Utrecht, Vakgroep Natuurwetenschap en Samenleving.

Luiten, E., 1999. Interne Notitie over aantal geïnstalleerde warmtepompen en het warmtepompenbeleid in Nederland Utrecht, Universiteit Utrecht, Vakgroep Natuurwetenschap en Samenleving.

Mac, A., 2002. When firms make sense of environmental agendas of society. Journal of Cleaner Technology 10, 259-269.

Mol, A.P.J., 1995. The Refinement of Production Ecological Modernization Theory and the Chemical Industry. Van Arkel, Utrecht.

Olsthoorn, M., 1993. De implementatie van energiezuinige meertrapsverdampers in de Nederlandse zuivelindustrie vanaf 1980 Utrecht, Universiteit Utrecht Vakgroep Natuurwetenschap en Samenleving.

Raad voor het Milieubeheer, 1996. Duurzame consumptie een reëel perspectief. Den Haag.

Reijnders, L., 1998. The factor X debate: setting targets for ecoefficiency. Industrial Ecology 2 (1), 13-22.

Rip, A., Kemp, R., 1998. Technological change. In: Rayner, S., Malone, E.L. (Eds.), Human Choice and Climate Change. Vol. 2. Battelle Press, Columbus, OH, pp. 327-399 (Chapter 6).

Rogers, E.M., 1995. Diffusion of Innovations, 4th edition. Free Press, New York.

Rooijers, F.J., Van Swigchem, J., 1996. Met de techniek op weg, implementatie van mechanische Dampcompressie. Delft: Centrum voor energiebesparing en schone technologie.

Schipper, L., Meyers, M., 1995. Energy Efficiency and Human Activity: Past Trends, Future Prospects. Cambridge University Press, Cambridge.

Stoneman, P., 1983. The Economic Analysis of Technological Change. Oxford University Press, Oxford.

Thirtle, C.G., Ruttan, V.W., 1987. The Role of Demand and Supply in the Generation and Diffusion of Technical Change. Harwood, Chur.

Van Brummelen, M., De Graaf, L., De Jager, D., 1998. Inventarisatie warmtepompen 1995-1997. Ecofys, Utrecht. 
Van der Doelen, F.C.J., 1989. Beleidsinstrumenten en energiebesparing: de toepassing en effectiviteit van voorlichting en subsidies gericht op energiebesparing in de industrie van 1977 tot 1987. Enschede, Bestuurskunde TU Twente.

Van der Waals, J., 2001. $\mathrm{CO}_{2}$ Reduction in housing experiences in building and urban renewal projects in the Netherlands, Amsterdam. Rozenberg Publishers, Ph.D. Thesis.

Verheul, H., 1999. How social networks influence the dissemination of cleaner technologie to SME's. Journal of Cleaner Technology 7, 213-219.
Vermeulen, W.J.V., 1992. De vervuiler betaald, Onderzoek naar de werking van milieusubsidies op vier deelterreinen van het milieubeleid. Van Arkel, Utrecht.

Von Weizsäcker, E.U., Lovins, A.B., Lovins, L.H., 1998. The Factor Four: Doubling Wealth, Halving Resource Use: the New Report to the Club of Rome. Earthscan, London.

Weterings, R., Opschoor, J.B., 1994. Towards Environmental Performance Indicators Based on the Notion of Environmental Space. Advisory Council for Research on Nature and Environment (RMNO), Rijswijk. 